This document is the author's version of an accepted manuscript of a published work that appeared in final form in Ageing and Society, copyright (C) Cambridge University Press, after peer review and technical editing by the publisher. To access the final edited and published work see [https://doi.org/10.1017/S0144686X19000138].

\title{
Maintaining the 'caring self' and working relationships: a critically informed analysis of meaning-construction among paid companions in long-term residential care
}

Laura M. Funk, $\mathrm{PhD} 1$, and Linda Outcalt, $\mathrm{PhD}(\mathrm{c})_{2}$ 1Associate Professor, Department of Sociology, University of Manitoba. 307-183 Dafoe Road, Isbister Building, Winnipeg, Manitoba, Canada R3T2N2. Phone: 204-474-6678 Fax: 204-2611216 Email: Laura.Funk@umanitoba.ca

${ }_{2} \mathrm{PhD}$ Candidate (Interdisciplinary Studies), Department of Sociology, University of Victoria. PO Box 3050 STN CSC, Victoria, B.C. V8W3P5. Phone: 250-721-7572 Fax: 250-721-6217. Email: loutcalt@uvic.ca 
This document is the author's version of an accepted manuscript of a published work that appeared in final form in Ageing and Society, copyright (C) Cambridge University Press, after peer review and technical editing by the publisher. To access the final edited and published work see [https://doi.org/10.1017/S0144686X19000138].

\section{Abstract}

In Canadian residential long-term care, paid companion services are increasingly viewed as helping to meet older adults' psychosocial needs. Complimenting the critique of these services from a political economy perspective, analyses of companions' talk about their work can illuminate not only why companions stay in devalued and often invisible work, but also how social assumptions and circulating narratives about nursing homes and older adults are implicated in this process. In this article we draw on in-depth analyses of interviews with both companions and organizational representatives. We interpret companions' accounts in relation to their need to justify the necessity for their work to their employers (families), to nurture good relationships with the facilities in which they work, and to maintain a sense of identity as a responsible, conscientious and "caring self" (Stacey 2011). In this way, these precarious workers inadvertently reproduce dominant narratives, including those that stigmatize dementia and residential care and facilitate the privatization of person-centred, relational care. Organizational representatives generally reproduce similar assumptions about care responsibilities, in a context in which facilities are increasingly challenged to meet a range of resident needs. Discussion highlights tensions around responsibility for psychosocial care in nursing homes, highlighting organizational vested interests in avoiding risk and downloading responsibilities to families and to private, independent and temporary workers.

Keywords: private companions; nursing homes; interpretive analysis; long-term care 
This document is the author's version of an accepted manuscript of a published work that appeared in final form in Ageing and Society, copyright (C) Cambridge University Press, after peer review and technical editing by the publisher. To access the final edited and published work see [https://doi.org/10.1017/S0144686X19000138].

Positive social interactions and psychosocial supports promote self-worth, identity, quality of life and quality of care among residents of long-term residential care facilities (Coughlan and Ward 2007; Vourlekis, Gelfand and Greene 1992). Despite increasing recognition of person-centred and relational care, meeting older residents' social, recreational, relational and emotional needs is increasingly challenging in Canada, as in other industrialized nations. Systemic health care changes mean that older adults now enter residential care at later, more dependent stages, yet staffing levels and abilities in these settings have generally not kept pace with the changing nature and complexity of needs (McGregor et al. 2010). Limited facility resources tend to be targeted towards medical and physical tasks rather than relational work, and psychosocial needs are only minimally addressed in legislated Canadian care home standards. 1 Although this work is highly valued by facility employees (Daly and Szebehely 2011) and contributes to person-centred care (Alzheimer Society of Canada 2014), there are few meaningful opportunities for social engagement (Harper Ice 2002; Hasson and Arnetz 2011). Moreover, geographic and time constraints limit families' capacities to address psychosocial needs (Keefe et al. 2012). Some facilities enlist volunteers, yet recruitment and retention can be an issue, and volunteers may also be constrained in developing long-term connections with residents (Funk and Roger 2017).

In light of these concerns, increasing research attention has been directed to the phenomenon of paid, private companions in Canada, hired by well-resourced families either through a private unregulated home care agency or independently (Brassolotto et al. 2017; Dergal 2011; Outcalt 2013). For institutionalized older adults, companions provide personalized 
This document is the author's version of an accepted manuscript of a published work that appeared in final form in Ageing and Society, copyright (C) Cambridge University Press, after peer review and technical editing by the publisher. To access the final edited and published work see [https://doi.org/10.1017/S0144686X19000138].

emotional and social support and companionship, and sometimes (in a limited or unofficial way) help with tasks such as transportation, feeding, and toileting (Daly, Armstrong and Lowndes 2015; Dergal 2011; Outcalt 2013). Employment relationships are typically between the companion and family (sometimes via a private agency), though some facilities recommend companions or hire them (e.g., on behalf of residents in public guardianship); some also register, orient, regulate and monitor companions working in the facility (Cossever 2006).

Previous analyses of private companions in both home based and long-term residential care settings have engaged political economy perspectives to illuminate how reliance on this work shifts eldercare responsibilities and costs away from the state and onto families and companions (Brassolotto et al. 2017; Degiuli 2010). Much like the nurturant work of care aides and assistants, paid companion work tends to be undervalued, liminal, precarious and invisible (Daly et al. 2015; Daly and Armstrong 2016; Duffy, Armenia and Stacey 2015). Moreover, it is unregulated; companions may have more autonomy than facility staff yet are denied many workplace benefits and protections (Daly and Armstrong 2016). This increases risks for companions and residents, and despite growing demand for these services, facilitates inequalities in access to social care (Brassolotto et al. 2017; Daly and Armstrong 2016).

Political economic and critical theoretical analyses of the paid care work of residential and home care aides have also explored how a variety of frontline care workers facing difficult work conditions and low pay tend to narratively construct dignity and feelings of ownership over their labour through maintaining a sense of a "caring self" (Stacey 2011; see also Brown and Korczynski 2017; Johnson 2015). Analyses of the narratives of paid companions (Outcalt 2013) and similarly positioned immigrant 'minders' (Degiuli 2016) for older adults in home based 
This document is the author's version of an accepted manuscript of a published work that appeared in final form in Ageing and Society, copyright (C) Cambridge University Press, after

peer review and technical editing by the publisher. To access the final edited and published work see [https://doi.org/10.1017/S0144686X19000138].

settings have examined the dynamics of power in relationships with family employers and how these workers, and their employers, construct fictive kin relationships for particular purposes. There is a dearth, however, of research examining how private companions interpret their work in long-term residential care. Given that companion work is precarious, and "seen as non-essential" within Canada's publicly funded health care system (Brassolotto et al. 2017: 65), how do companions position their work and maintain valued identities? Further, although narrative data from care workers have been used to examine why these workers might stay in challenging jobs (Degiuli 2016; Stacey 2011), devote extra effort to providing meaningful care (Brown and Korczynski 2017; Dodson and Zincavage 2007), and in some cases challenge organisations’ economic goals (Johnson 2015), companions' talk about their work can also illuminate broader shared assumptions and public narratives about residential care and older adults. In this paper we explore and critically examine how companions interpret the meaning of residential companion work in one central Canadian city, comparing these accounts against those from organizational representatives, to widen the discursive gaze of our inquiry.

\section{Methods}

Context and Geographic Site. In the province of Manitoba (Canada), long-term residential care facilities are supervised spaces with access to 24-hour nursing care, personal care and other services (e.g., provincial legislation requires recreational activities). About 12 per cent of people aged 75+ live in residential care (Centre on Aging 2014); these facilities are publicly funded (via regional health authorities) and regulated and delivered on a for-profit or not-for-profit basis. They are provincially insured and regulated; most are accredited through a national non-profit 
This document is the author's version of an accepted manuscript of a published work that appeared in final form in Ageing and Society, copyright (C) Cambridge University Press, after peer review and technical editing by the publisher. To access the final edited and published work see [https://doi.org/10.1017/S0144686X19000138].

organization (Daly et al. 2016). Costs are partly subsidized, with residents paying monthly means-tested fees. Normally, residential care is accessed by older adults requiring a certain level of care as assessed by a regional health agency. There are growing proportions of residents with advanced cognitive impairment and significant care needs, and there is a relatively high risk of violence in these facilities (Banerjee et al. 2012). There has been little change in staffing ratios over the years in Canada despite increasing care needs - in Manitoba, estimates range from 3.4 to 3.1 combined hours of registered nurse and aide care per resident per day, which does not reflect administrative work, indirect care and so on (Doupe et al. 2006; Manitoba Nurses Union 2018). Social care is normally the formal responsibility of recreation workers, 2 although social and spiritual care workers may also play a role. Unregulated care aides perform the bulk of overall care, helping with social needs when they have time (Daly et al. 2016; Novek 2013). About half of Canadian nursing home residents are estimated to have limited to no social engagement (Canadian Institute for Health Information 2013).3

Design. A qualitative design is appropriate for examining constructed, circulating meanings of residential paid companion work. Following institutional REB approval (and where required, institutional REB approval), 60 local care homes and hospital long-term geriatric units in Winnipeg were asked to distribute study information to known companions working in each facility (11 facilities confirmed distribution). No companions were directly employed by facilities. We also invited facility managers, care directors, social workers, volunteer supervisors (who often informally monitor companions), union representatives, and home care agencies at these facilities to participate. Our goal in doing so was to examine interpretations of the expected work of companions in specific facilities and agencies. Advertisements were also circulated 
This document is the author's version of an accepted manuscript of a published work that appeared in final form in Ageing and Society, copyright (C) Cambridge University Press, after peer review and technical editing by the publisher. To access the final edited and published work see [https://doi.org/10.1017/S0144686X19000138].

through an ageing research centre, community papers, and three private home care agencies.

Potential participants contacted the first author directly.

Data Collection and Analysis. In-person qualitative interviews conducted by a research assistant and the first author were digitally recorded and transcribed verbatim; broad questions elicited interpretations of companions' work and role. After repeated readings of transcriptions, descriptive summaries were created for each participant reflecting preliminary descriptive coding focused on the content of accounts. Subsequent analyses were informed by interpretive inquiry (Gubrium and Holstein 2000), which directs attention to how participants draw on cultural stocks of knowledge as frameworks to construct meaning. In other words, the analysis focused on the interpretive goals informing paid companions' talk about their work; specifically, how they justified the need for this work to themselves and others. This analysis moved beyond simple readings of what participants said to examine how and why they spoke about it in particular ways as well as to critical consideration of the broader discourses they drew on in their talk. Both descriptive and interpretive findings were compared and contrasted between participants, and between participants and the facility and agency representatives. Themes reflecting this analysis are presented below.

Participant Description. Nineteen companion participants included six who worked independently and 13 who worked for private home care agencies. An additional nine participants included eight facility representatives (e.g., social workers, recreation supervisors, CEOs), and one owner of a private home care agency. Companions' ages ranged between 20-66 years; only one was male. All but two identified as Caucasian, Canadian, or of European descent (two identified as Indigenous); none were recent immigrants. Three had health care aide training. 
This document is the author's version of an accepted manuscript of a published work that appeared in final form in Ageing and Society, copyright (C) Cambridge University Press, after peer review and technical editing by the publisher. To access the final edited and published work see [https://doi.org/10.1017/S0144686X19000138].

Their length of time in the role ranged from four months to 15 years (average: 4.05 years). Companions reported currently working with between 1 and 13 clients, with hours varying widely by month to month, often between two and five hours per week per client. Paid companion work is in constant flux as clients die or are hospitalized, new ones are added or agency workers are reassigned, and so on.

\section{Findings}

Narrative justification of companion work as a response to liminality. Data from both companions and organizational representatives supported our first (and over-arching) interpretive theme, in which we explore paid companions' narratives as in part representing their attempts to maintain valued identities. Since companion work is often devalued, liminal and underrecognized, the value and worth of their role, and in some cases the very need for it, may be questioned by others, especially in residential care (see also Brassolotto et al. 2017; Daly, Armstrong and Lowndes 2015). As such, participants' narratives reflect a need to justify their work to themselves and to expected perspectives of others (Mead 1934; Stacey 2011).

The most obvious signifiers of low value - the low pay and precarious nature of the work - were compounded by situations in which companions described their role being questioned or critiqued by others. For instance, one independent companion mentioned that some family members question how much and why she is being paid for her work, adding, "I have to show why am I so important to you, to your mom." Another independent companion stated: "many people think that this should all be volunteer work" and added: "I'd love to be able to do it volunteer, but I have to make a living too." Likewise, an agency companion emphasized that her time is sufficiently valuable to warrant payment (rather than volunteering). 
This document is the author's version of an accepted manuscript of a published work that appeared in final form in Ageing and Society, copyright (C) Cambridge University Press, after peer review and technical editing by the publisher. To access the final edited and published work see [https://doi.org/10.1017/S0144686X19000138].

Even companions themselves sometimes even reflected that they did not always know whether they made a difference in their work, as in the following excerpt:

I don't get a lot of feedback [from staff] on what [the client is] like, after - if I really did help that day. I try to do a good job... I do feel like I want to do more but I'm not sure how, I only have a few hours time. I guess in my couple hours I'm usually happy with what I did. (Independent companion)

Feedback and validation were challenging when resident-clients could not easily communicate appreciation to their companions; in these cases, appreciation from others (family, staff) were highly valued external sources of validation. As such, companions may have been particularly sensitive to experiences involving symbolic expressions of rejection or devaluation (and some expressed distress stemming from these experiences). Companions described times in which facility workers were standoffish, not acknowledging or thanking them, or communicating in a negative tone of voice. One independent companion indicated:

I'll get little comments once in a while from recreation staff, I'm not sure where they stand, I don't ever want them to think I'm a threat of any kind because they have their programmes but they can only do so much... Sometimes I feel maybe there's a bit of a 'feeling' there.

Facility representatives supported companions' claims in this regard by explaining that facility staff often resent companions who yell at or manipulate staff, have unreasonable expectations, demand private medical information, are overly controlling of resident care, or circumvent staff and speak directly with family about concerns. The owner of a private care agency also confirmed that companions can be unwelcome: 
This document is the author's version of an accepted manuscript of a published work that appeared in final form in Ageing and Society, copyright (C) Cambridge University Press, after peer review and technical editing by the publisher. To access the final edited and published work see [https://doi.org/10.1017/S0144686X19000138].

\begin{abstract}
At first [facility staff] are really resistant to having companions there that are not hired by the facility because they feel like it's showing that they're not doing their job properly. So the family hired someone to provide service because they're not doing their job right. So then [facility staff] become really protective, and they can be really critical.
\end{abstract}

Moreover, although facility representatives generally characterized companions as positive, they also spoke of risks involved, for instance when companions were neglectful (e.g., "more busy looking for the next job than spending time with that elder. Networking with all the families, are you doing what you're paid for?" (Facility CEO). One organizational representative also suggested that money that families spent on companions would be better spent towards hiring another health care aide or recreation worker: "we could do it if we had the cash."

In sum, companions' accounts of their work can be viewed as narrative justifications of the value of their work. Companions are likely aware that they are doing work that could (or even should) be done by a paid health care aide or recreational staff person: indeed, as one agency companion noted: “[facility staff] kept saying, 'too bad you couldn't work here on the right team.'" It is within this context that we need to understand how and why companions sought to distinguish their work as distinct, essential, and helpful within their narratives. How they did this (and how these ideas intersect with the narratives of organizational representatives) is illustrated in additional themes presented below.

Establishing the facility care gap: the lack of one-to-one contact. Our data further indicate that residential care companion services are positioned discursively as supporting older residents' social and recreational needs in the context of gaps in such care (see also Brassolotto et al. 2017). 
This document is the author's version of an accepted manuscript of a published work that appeared in final form in Ageing and Society, copyright (C) Cambridge University Press, after peer review and technical editing by the publisher. To access the final edited and published work see [https://doi.org/10.1017/S0144686X19000138].

Facility operators sometimes need to formally justify the engagement of paid companions in their facility; for instance, one care director described negotiating with unionized facility staff when introducing a formalized private companion programme (that actively coordinated and facilitated these services). To justify why they would not just hire more care staff, the participant explained how her facility invoked a vague dichotomization of concepts of "care" and "contact," although also alluded to workload pressures:

... socialization is a part of what paid staff do but they're trying to do it for a large number of people and there are times when people need one to one contact. There are times when people need one to one care, but there are times when they just need one to one contact.

For both private agencies and companions, positioning companion work as filling a resource-based care gap is also an important part of establishing positive, non-threatening relationships with facility staff: "we're not here because you're not doing your job right. We're here to support you because we know you can't do everything for this person" (Private care agency owner). Echoing this idea, companion participants linked the need for their services to a lack of one-to-one relational time for paid facility staff. They emphasized how they are uniquely positioned to develop connections with residents, contrasting their ability and time against that of facility employees faced with heavy workloads. One agency companion described facility workers as "run off their feet" dealing with daily needs: "they can't sit with someone for three hours which, I have a luxury... being able to do that." An independent companion further reflected facility staff workloads: "they talk about quality care, and it's like four people?! You 
This document is the author's version of an accepted manuscript of a published work that appeared in final form in Ageing and Society, copyright (C) Cambridge University Press, after peer review and technical editing by the publisher. To access the final edited and published work see [https://doi.org/10.1017/S0144686X19000138].

can't possibly look after anybody properly with that." Another independent companion expressed:

It's a very important position to be here as a companion because [residents] can get terribly lonely, like after dinner. Even during the day sometimes because the staff just doesn't have time to be here all the time.

One agency companion who previously worked as a care aide remarked on the lack of relational interaction, interpersonal contact, and ability to provide personalized care in that role:

You don't have time to sit with somebody and take five minutes and say, 'so, how are you feeling today?' or 'so and so's coming to visit'. It's just - get you up, get you washed, get you toileted, get you dressed, get you to the dining room, feed you, get you back. And that's it. And I had a couple [residents] in the nursing home that I felt really close to, but yet I didn't have the time I do now... But in a nursing home you very might have an extra two minutes or something and so I don't like the rushed structure and it is all 'dollars.'

An agency companion and one director of care also expressed a belief that volunteers are less able than companions to fill these gaps, because they are usually engaged in delivering group programmes rather than developing meaningful relationships over time with particular residents.

In these narratives, facility staff generally tended to be characterized as struggling to do their best to meet psychosocial needs within workload constraints but as needing some help. In some cases, companion participants implied or directly implicated characteristics of facility staff or volunteers as contributing to these gaps. As one example, an agency companion noted: "the fact that there were some pretty crappy caregivers in the facilities that weren't helping [client with social/emotional needs], that also makes me want to do it even more." In another example, 
This document is the author's version of an accepted manuscript of a published work that appeared in final form in Ageing and Society, copyright (C) Cambridge University Press, after peer review and technical editing by the publisher. To access the final edited and published work see [https://doi.org/10.1017/S0144686X19000138].

an agency companion described her grief and bereavement when clients die as reflecting her emotional connections with clients. She then suggested that nursing home staff lack compassion and are emotionally 'hardened':

I mourn them [like I do a friend] because I do let myself get close to them and I don't see why not. Maybe that's part of the problem in the facilities is that sometimes [the residents] are only there for a few months...two years tops and those aides and nurses have just hardened because they've seen it happen so many times and that's how they deal with it.

Another agency companion contrasted her own approach against that of facility staff:

I find [facility care] very impersonal... they don't try to learn who the person is, they just see, you have dementia... whereas I had spent so much time with her when she wasn't as far declined, so I would listen to music with her, and sing songs with her, and you could see her kind of break out of that shell and she'd start singing, and it was her again. But I found they won't find the ways to do that, they just try to do the medical side of it, and well, she's healthy in this sense, so ... that was a little upsetting.

Having established important psychosocial care gaps in the facility, companions positioned their work as filling these gaps, describing their work as enriching residents' quality of life, emotional support, socialization and integration, and human connection.

In these ways, participants actively drew on ideas about a crisis in health care for older adults, manifesting here as concerns about the inadvertent social neglect of residents in the context of staffing limitations and workloads. Participant narratives further reproduced the idea, 
This document is the author's version of an accepted manuscript of a published work that appeared in final form in Ageing and Society, copyright (C) Cambridge University Press, after peer review and technical editing by the publisher. To access the final edited and published work see [https://doi.org/10.1017/S0144686X19000138].

however, that the work of social care should not be the purview of paid facility staff, whose role should be to focus on medical and task-based forms of care.

The production of moral value. In alignment with their stated role, companions emphasized the friend and fictive kin nature of their connections with residents (e.g., "I just call them all my friends"), reinforcing their own caring natures and identities as they distinguished their work from that of paid facility staff. Another way they did this was by emphasizing the personalized supports they provided to clients (e.g., creating personalized music compilations, personalizing the boards outside resident rooms, helping clients watch favourite television programmes, maintaining individualized grooming and clothing styles). One independent companion referred to this as "doting" (i.e., an expression of love), and another as treating the client "like family":

I make sure that they are looking good all the time ... just like I would treat my mom. My parents have passed away and I'm kind of doing I guess the same thing that I would've done for them. They're an extension of my family and just the way I would want my mom and dad to be treated.

Another way in which companions prioritized relational aspects of their work, affection and caring was to highlight how they went "above and beyond" in their work. As one independent companion stated, "I consider them more than just clients. They're a friend, therefore if you are a good friend, you would do what you can for your friend." Additional excerpts from other participants include: "I have not run into any client...that I did not like and did not go the extra mile for"; "I do go above and beyond what is required of me...I'm glad to help"; and "I did way more with them than [the family] ever expected me to." 
This document is the author's version of an accepted manuscript of a published work that appeared in final form in Ageing and Society, copyright (C) Cambridge University Press, after peer review and technical editing by the publisher. To access the final edited and published work see [https://doi.org/10.1017/S0144686X19000138].

Some companions described contributing unpaid time if needed or purchasing small items for their client with personal money. These narratives posit affection and caring identities as the true motivations for companion work and may bolster the sense of distinct moral value in companion work. One independent companion, for example, described not charging mileage or increasing her price when a client moved [despite a longer drive], and her account reinforced her claims about the quality of her relationships with clients as well as her caring identity:

... and that is not paid, that is because it's who I am. Everybody says you have to be a special person and I says 'well I'm just me', but come to think of it, not many people would go that far.

Positioning their work as "little extras" likely served another important function - to help companions (and organizational representatives) ensure companion work was not viewed as encroaching upon the scope of publicly funded (and sometimes unionized) facility services.

Participants also explained that their work does not feel like a job, e.g., "because I enjoy it." In this way, they reinforced internal and caring motivations. Notably, a common critique of residential care facility staff is that they are doing the work 'just for the job' or pay (Cooke, Puurveen and Baumbusch 2017), and companions indirectly contributed to this critique by distancing themselves from monetary aspect of their work, as in this excerpt:

You have to love people, you can't just do it because it's a job. That bothers me if people are just doing it for a job. (Agency companion) 
This document is the author's version of an accepted manuscript of a published work that appeared in final form in Ageing and Society, copyright (C) Cambridge University Press, after peer review and technical editing by the publisher. To access the final edited and published work see [https://doi.org/10.1017/S0144686X19000138].

Although organizational representatives generally echoed companion narratives of "not doing it as just a job" and "going above and beyond" (especially when speaking of independent companions), some expressed concerns about whether or not companions could maintain professional boundaries; contributing personal money, for instance, was interpreted as inappropriate or exceeding role boundaries.

Emotionally connected, friend and kin-like relationships also tended to be characterized by companions as a source of enjoyment and reward in the work, as in: "it's just like a nice feeling...when I had a week off, I miss [client]! He almost feels like a grandpa, or a dad. Closer to a dad." Although participants emphasized that building these relationships takes work and skill, at least one companion positioned herself as innately positioned to do the work:

I think I have patience. You know a lot of people don't. I just I think I have a gift to do it. I don't want to put myself up on a pedestal but I just feel I can do [for] them, like no effort or something.

Agency companions generally expressed a greater sense of being constrained in developing close connections, for instance by organizational directives emphasizing professionalism in their agencies. This could include agency policies requiring workers to wear uniforms; to address clients by their formal titles; or not to disclose aspects of their personal lives to clients were viewed by agency-employed participants as bureaucratic, formal barriers to establishing close relationships and connections. In contrast, independently employed companions tended to more commonly emphasize fictive kin relationships and personalized aspects of care. Though this may in part reflect their greater ability to nurture close relationships, 
This document is the author's version of an accepted manuscript of a published work that appeared in final form in Ageing and Society, copyright (C) Cambridge University Press, after peer review and technical editing by the publisher. To access the final edited and published work see [https://doi.org/10.1017/S0144686X19000138].

independent companions' work is arguably more precarious, and this may have motivated narrative efforts to position these elements as part of the added value of their service.

By downplaying the employment aspects of their role and foregrounding caring identities and motivations, participants' narratives reproduce the assumption that payment for caring is somehow worth less than altruistic or voluntary forms of care. Folbre and Nelson (2000) emphasized a need to move away from an either/or distinction between economic self-interest and caring motivation, instead viewing economic payment as "acknowledgement and appreciation of the worker's own intrinsic motivations" (133).

An emphasis on fictive kin and altruistic motivation has been noted in other studies of companions and workers in residential care (Dodson and Zincavage 2007; Outcalt 2013) and has been connected to the naturalisation of emotional labour (Hochshild 1983; Johnson 2015) within organizations and among workers. It is unclear in the present study whether or how the facilities in which participants worked, or agencies for which some were employed, actively encouraged companions to align with family care ideologies - indeed, some organizational representatives emphasized emotional boundaries. Daly and Armstrong (2016) suggest these pressures can come directly from families.

By themselves actively invoking fictive kin ideologies, companions can be viewed as inadvertently contributing to the devaluing and invisibility of their own work in economic terms, potentially enhancing their vulnerability to exploitation while also reproducing gendered and often racialized ideals about caring (Dodson and Zincavage 2007; Stacey 2005).

Helping not hindering: The "sliding scope" of companion work. Although companions sought to distinguish their work from that of facility staff, they were also aware that to meet client needs 
This document is the author's version of an accepted manuscript of a published work that appeared in final form in Ageing and Society, copyright (C) Cambridge University Press, after peer review and technical editing by the publisher. To access the final edited and published work see [https://doi.org/10.1017/S0144686X19000138].

in the facility work environment, they had to engage with facility staff in a positive and helpful manner that may help mitigate potential resentment towards them stemming from the position they hold. Trusting, positive relationships with facility staff (e.g., "not stepping on their toes") can be instrumental, so that the companion can work effectively. For instance, one independent companion explained how she nurtures relationships with staff so that they will provide her with needed information and the ability to do certain things with the client (e.g., take them to an event): "I have to keep the nurses happy for your mother's sake." Strong relationships with staff could also facilitate future work opportunities (i.e., when staff actively recommend companions to other families).

Given that staff may feel threatened by companions' presence in the facility, companions spoke about how their work benefits staff, and positioned their roles not just as filling a resource gap (as earlier), but as actively benefitting staff. Most directly, when companions occupy their own clients, this creates opportunities for facility staff to focus on the care of other residents or other aspects of resident care. Companions spoke of helping ease care aide workloads in phrases such as "one less to worry about"; they described keeping their own clients occupied and helping to distract and redirect clients who may be prone to agitation. As one independent companion noted: "it's helpful because [staff] don't have the time to sit there and be with her...So it's times like that that I can be a big help for the staff, the nurses..." Lastly, one agency companion, after expressing her distress when treated poorly by facility staff (e.g., they don't know her name), added: "[facility staff] should be happy I'm here because I'm giving you a break by taking this client away from you for a while." 
This document is the author's version of an accepted manuscript of a published work that appeared in final form in Ageing and Society, copyright (C) Cambridge University Press, after peer review and technical editing by the publisher. To access the final edited and published work see [https://doi.org/10.1017/S0144686X19000138].

Companions spoke about helping out non-client residents, characterized as an unprompted, conscientious response to need (e.g., as reflecting a caring identity). This could include conversing with non-client residents or helping them participate in recreational programmes, or in one instance, distributing food at events: "I know I didn't have to, but it was just [client] was fine by herself at that point, so I would do stuff like that" (Agency companion).

Participant talk about conscientious helping indicated a point at which the scope of companion work can potentially creep beyond social forms of care. Data from some of the organizational representatives we spoke with indicated that in some facilities, companions that were trained as health care aides were explicitly tasked with hands on personal care during the initial transition into a care facility, during medical crises and hospitalization, or at the end of life. None of the companions we recruited, however, appeared to be engaged in such an explicit and formalized way in personal care. However, some companions described lifting or transferring their own clients, and occasionally helping monitor or assisting them during showering or toileting. As identified by Brassolotto et al. (2017), in some cases this was motivated by a dominant concern for their client, who may be faced with a long wait when care aides are busy (e.g., moral distress). Although requests for this kind of help from staff were rare, companions positioned themselves as strongly motivated to help out facility staff, and this was often met with appreciation. For example, one independent companion explained how the workers tell her that she is "part of the [facility staff] family":

They couldn't be happier because I've not only provided the services for the resident importantly and the families, but I'm helping the staff as well. I'm that quiet person over there saying 'I'll wash their face and 
This document is the author's version of an accepted manuscript of a published work that appeared in final form in Ageing and Society, copyright (C) Cambridge University Press, after peer review and technical editing by the publisher. To access the final edited and published work see [https://doi.org/10.1017/S0144686X19000138].

brush their teeth and give you a chance to do something else' so it's helping the staff. I'm not a hindrance to the staff, I'm helpful to them.

Another independent companion explained that when the facility is short staffed, she will often feed her client as well as shave him and change his clothes: "it's not really in my job description, but I do it." An agency companion further described her work with a residential client:

I direct her and help her change her clothes, put on her pajamas. Not in my job description, but I do it for her and I know the staff appreciate it [laughs] because they would have to do it if I didn't do it. And technically they should be doing it but I don't mind doing that.

Another agency companion who had training and experience as a care aide stated: "I help feed that client or put away dishes or I'll do this or that, whatever. I'm a helpful person that way, I don't say 'that's not my job' [laughs] or anything like that.”

Alongside, and sometimes countering this desire to be helpful, however, was a strong sense of the personal risk involved in non-social forms of help, such as lifting heavy clients, and this motivated many companions to limit their involvement in personal care tasks, even when requested to help by paid care staff. Some organizational representatives expressed similar concerns from a risk management perspective (e.g., potential harm to residents). One representative also raised concern that staff might become overly reliant on companions: "our responsibility is to provide that care for every resident here. So we shouldn't be stepping back and waiting for someone else to provide that care" (Recreation manager). 
This document is the author's version of an accepted manuscript of a published work that appeared in final form in Ageing and Society, copyright (C) Cambridge University Press, after peer review and technical editing by the publisher. To access the final edited and published work see [https://doi.org/10.1017/S0144686X19000138].

Drawing on and reproducing fear and anxiety about facility care. Over the last decade, several high-profile cases of abuse have been covered in Canadian media, as in other countries (Lloyd et al. 2014). In their study of media depictions in the U.S., Miller et al. (2012) concluded that "the predominantly negative media reports contribute to the poor public opinion of nursing homes and, in turn, of the people who live and work in them" (725). Though comprehensive data on public attitudes towards Canadian nursing home care is lacking, qualitative research has documented families' concerns about care gaps and resident safety, often as these motivate their involvement in advocacy and monitoring (e.g., Barken, Daly and Armstrong 2016).

This broad public distrust and even fear of nursing homes can be viewed as providing opportunities for companions to further legitimize their involvement in non-social aspects of resident care. In one excerpt, an independent companion explained that facility staff do not have the time needed to feed her client. In contrast, a recreation supervisor explained that one of the drawbacks of companions in her facility was an assumption that develops among family members that if they do not have a companion, the resident would not get fed. She believed some paid companions have a vested interest in perpetuating perceptions of inadequate attention to feeding needs, to ensure they have ongoing sources of clients. Another example highlights the irony involved: the representative of a different facility looked favourably on companions who also were trained as care aides, and explained how in these situations, there is no need for facility staff to be present. She then complained, however, that some companions tell families that "staff never come in the room" or provide care, which can harm the facility's image.

Public distrust and anxiety about residential care quality and safety further helps companions distinguish a role as resident advocates, and as such, several spoke of advocating, 
This document is the author's version of an accepted manuscript of a published work that appeared in final form in Ageing and Society, copyright (C) Cambridge University Press, after peer review and technical editing by the publisher. To access the final edited and published work see [https://doi.org/10.1017/S0144686X19000138].

monitoring the daily life and care of the resident, or liaising between the resident and the staff. This included identifying and pointing out issues of concern for the residents' quality of life or medical condition, or relaying client complaints, needs and preferences to facility staff or family. For example, one independent companion stated:

[Resident-client] may be laying in stool or in urine and [the staff say] 'we only do it every two hours.' Well she wants [to be changed] right now. I say, 'can you come back maybe and I can delay her for 15 minutes but could you come back a little sooner after shift change or something like that?' I'm negotiating with them so that my client's not too long in there ...

Independent companions may have more ability to advocate, as agency companions can be limited by policies prohibiting direct communication with family or staff (i.e., they must relay concerns through the agency).

Although organizational representatives sometimes characterized companion advocacy as beneficial (e.g., when companions identify safety issues or when families live out of province), they were concerned about what they characterized as inappropriate advocacy - for instance, when companions lacking background or expert knowledge try to manipulate staff or interfere with how care is provided to non-client residents. These characterizations reinforce companions' marginalization as peripheral workers, rather than as part of the care team.

Companions (especially independent companions) frequently characterized the monitoring and advocacy aspects of their work as helping families, including being the family's 'eyes and ears,' and easing families' worries and burden. In this way, companions also position themselves as filling a family (as opposed to facility) care gap, normally due to geographic 
This document is the author's version of an accepted manuscript of a published work that appeared in final form in Ageing and Society, copyright (C) Cambridge University Press, after peer review and technical editing by the publisher. To access the final edited and published work see [https://doi.org/10.1017/S0144686X19000138].

distance. For example, one independent companion stated: 'I'm an extension of the families' eyes and ears and a lot of times the families are either far, far away and I can phone them and advise them of what I see." An agency companion further reported:

I'm just there twice a week, but [client's son] says there's a lot less anxiety so I guess indirectly I'm helping families by taking a bit of the load off. I hope so. That's kind of my goal. And the other family, people with kids into activities and full-time jobs and how much time do they have to go running for elderly parents with dementia... who may be sleeping when they get there? So hopefully I'm helping relieve some of that.

Agency companions were less likely to emphasize helping families, perhaps in part because they have less direct interaction with families (i.e., who are not their direct employer).

In sum, through recounting stories in which they noticed and responded to quality concerns or errors in facility care, companions emphasized the need for and importance of their own work while drawing on and reinforcing distrust, anxiety and fear about facility care.

\section{Drawing the line at behavioural management while reproducing dementia stigma. The} increasing complexity of resident care needs (including cognitive impairment) in Canadian facilities has been well documented and can contribute to experiences of workplace violence (Banerjee et al. 2012) and other resident behaviours that can be difficult or time-consuming for staff to respond to. In the region in which the present research was conducted, an estimated 63 per cent of facility residents have moderate to severe cognitive impairment (Canadian Institute for Health Information 2013). There has also been increasing media attention to workplace violence; unions have raised concerns about resident acuity and dependency levels, given the lack of staffing increases (Manitoba Nurses Union 2006). 
This document is the author's version of an accepted manuscript of a published work that appeared in final form in Ageing and Society, copyright (C) Cambridge University Press, after peer review and technical editing by the publisher. To access the final edited and published work see [https://doi.org/10.1017/S0144686X19000138].

Several organizational representatives in this study characterized paid companions as a helpful way for facilities to help manage residents with advanced dementia who exhibit agitation, responsive and reactive behaviours, in part to alleviate the burden on facility staff. The recreation worker at one facility noted that in part due to inadequate funding for recreational staff, his facility encourages the use of companions for residents with reactive or potentially violent behaviour. A social worker at another facility added: "if we need a paid companion, it's not for 'happy Joe'.... it's for someone who is verbally or physically responsive, anxious, angst ridden.” The owner of a private care agency explained how companions in her agency are employed by families for this reason, for instance to help reduce agitation during 'sundowning' hours.

Tthe perspectives of companions and organizational representatives differed markedly on behavioural management. Companions very rarely emphasized their roles in behavior management. One exception is an independent companion who described how, because of the nature of her relationship with one of her clients with dementia, she evades the brunt of the woman's reactive behaviour: "there's one lady she can snap at me once in a while, not very often, but she's difficult with the staff, but I'm her friend, I'm not staff, so it is different so I don't get that same thing." Yet overall, the dominant companion narrative was of the emotional struggle of working with clients who express screaming, agitation, socially inappropriate behaviour, mood swings and negative moods, coarse or rude language and forms of aggression. As one agency companion reflected: "sometimes I'm emotionally beat at the end of the day." More broadly, companions described the challenge and effort in trying to understand and develop personal connection with clients with communication difficulties, dementia or responsive behaviour (companions often receive little to no training in these skills). 
This document is the author's version of an accepted manuscript of a published work that appeared in final form in Ageing and Society, copyright (C) Cambridge University Press, after peer review and technical editing by the publisher. To access the final edited and published work see [https://doi.org/10.1017/S0144686X19000138].

Several companions drew on related narratives about the inability of residents with advanced dementia to benefit from social interaction, in explaining their preference not to work with these clients. Three excerpts serve as examples:

If someone has severe dementia you're not building a relationship. They're not going to remember you if you come back a month later. It's limited. .... (Agency companion)

[Resident-client] just really regressed and there's no real conversation going between us, she just wants to go to bed after lunch. She doesn't recognise me, she has advanced dementia and I just felt like I wasn't benefiting her to have a visit anymore... (Agency companion)

This may sound a bit selfish, if I can help them and talk to them... I'm getting something out of it but I just... I can't do the other anymore and this is me. (Agency companion).

In their talk about who benefits most from their services, companions defined and asserted control over their work boundaries and working conditions at the same time as legitimizing their services. Agency companions may have less ability than independent companions to choose their clients, however; moreover, for all companions, economic necessity may dominate. Yet the relative absence of in-depth training, workplace supports and disability benefits may contribute to companions' hesitation about working with residents with advanced dementia or those who may be potentially aggressive. In downplaying their effectiveness working with residents with advanced dementia, companions may draw on and inadvertently reproduce the stigma of dementia - the assumption that residents with advanced dementia do not 
This document is the author's version of an accepted manuscript of a published work that appeared in final form in Ageing and Society, copyright (C) Cambridge University Press, after peer review and technical editing by the publisher. To access the final edited and published work see [https://doi.org/10.1017/S0144686X19000138].

benefit from social interaction. Such ideas can contribute to stigmatization and social exclusion of these residents within nursing homes (Bruce 2004; Dobbs et al. 2008).

\section{Discussion}

In part, companions' role interpretations may vary depending on their client's needs (which change over time), client and family requests and expectations, companions' preferences and skills, and implicit or explicit expectations within particular care facilities (and agencies, as relevant). Our approach extends attention to how and why participants, in their talk about their work, emphasize certain aspects over others (e.g., to assert the value of their work to themselves and others, to set boundaries, etc.), and draw on broader understandings of care and ageing in the process. Although the descriptive findings of this study generally confirm findings in other research on companions (Brassolotto et al. 2017; Daly, Armstrong and Lowdnes 2015; Daly and Armstrong 2016), the unique contribution of this paper is its explicit, in-depth focus on criticallyinformed interpretations of narratives. The aim is not to judge companions for the meanings they invoke, but to understand why and how they talk about care, nursing homes, and older adults in particular ways and to reflect on how this talk might reinforce broader discourses. One caveat is that the companions we were able to recruit largely reflected the dominant ethnic majority of the setting, and were not recent immigrants. Future projects should direct attention to the latter groups, to ascertain interpretive variations in this regard.

Companions presented their roles as simultaneously both essential (given care gaps) and optional (i.e., services 'above and beyond'); this tension likely reflects their liminal position, especially for independently hired companions (Daly, Armstrong and Lowndes 2015). However, 
This document is the author's version of an accepted manuscript of a published work that appeared in final form in Ageing and Society, copyright (C) Cambridge University Press, after peer review and technical editing by the publisher. To access the final edited and published work see [https://doi.org/10.1017/S0144686X19000138].

in positioning their role and suitability for psychosocial care provision, companions may inadvertently imply that paid facility employees do not or should not take the time to establish social interaction and emotional connections with residents (or do not value this). Moreover, in distinguishing the private companion role from that of facility staff, facility representatives and independent and agency companions alike promoted a dichotomy between tasks and relational or emotional care, for the most part positioning the former as the responsibility of paid facility staff (potentially unionized) and the latter as the responsibility of independent or agency companions precarious workers paid for by families.

As companions sought to justify the need for their work within facilities, strengthen relationships with staff, delimit the boundaries of their responsibilities, and establish control over (and dignity within) their work, they inadvertently drew on and reproduced other narratives, including fear and stigmatization of the 'fourth age' of nursing homes and dementia (Gilleard and Higgs 2010; McParland, Kelly and Innes 2017); and the ideology of fictive kin in paid care (i.e., the privileging of unpaid and altruistic care and the belief that payment for care is less moral). They also tended to emphasize their own responsibility for residents' wellbeing, which may not only produce anxiety when residents decline over time (Degiuli 2016) or do not respond as hoped, but might also threaten residents' own personhood and independence (Shenk 2009).

Further research should trace the contours of these companion narratives within private home care agencies (that supply some of these workers to families and facilities) and the nursing homes and even care staff that might have vested interest in avoiding risk and downloading responsibilities to families, precarious workers, and private agencies. That some organizational representatives in this study viewed companions as appropriate for personal care and behavioural 
This document is the author's version of an accepted manuscript of a published work that appeared in final form in Ageing and Society, copyright (C) Cambridge University Press, after peer review and technical editing by the publisher. To access the final edited and published work see [https://doi.org/10.1017/S0144686X19000138].

management evidences the slow and subtle creep of privatization. The ambiguity surrounding companion roles may be actively exploited by some residential care organizations; private agencies may actively capitalize on regulatory and role ambiguity. In the present study, companions (and organizational representatives) identified workload-related barriers to emotional and relational resident care, yet did not advocate for structural changes to support paid employees to meet these needs in all residents. Indeed, they sometimes implied that the attitudes of facility staff (e.g., cold, impersonal) were part of the problem. The solution was posited as their own form of privatized work; the lack of expressed concern about the inequities this generates facilitates the privatization of person-centred, relational care work. A companion service is unavailable to those who cannot afford it, generating care inequities. Moreover, some residents and families without adequate resources may struggle to finance additional private support at great cost to their own well-being (e.g., second mortgages, bank loans, etc.). There is pressing need to consider how future demographic, political and economic trends will shape how residential care organizations utilize these often-silent workforces, how the service is experienced and interpreted by paid companions, families, and care staff, and how older adults of all socioeconomic backgrounds may be affected by such changes. 
This document is the author's version of an accepted manuscript of a published work that appeared in final form in Ageing and Society, copyright (C) Cambridge University Press, after

peer review and technical editing by the publisher. To access the final edited and published work see [https://doi.org/10.1017/S0144686X19000138].

\section{References}

Alzheimer Society of Canada. (2014). PC P.E.A.R.L.S.TM: 7 key elements of person-centred care of people with dementia in long-term care homes. Accessed at: http://www.alzheimer.ca/sites/default/files/Files/national/Culturechange/PCPEARLS_full_e.pdf

Armstrong, H., Daly, T.J., \& Choiniere, J.A. (2016). Policies and practices: The case of RAIMDS in Canadian long-term care homes. Journal of Canadian Studies, 50(2), 348-367. Doi:10.3138/jcs.50.2.348

Banerjee, A., Daly, T., Armstrong, P., Szebehely, M., Armstrong, H., \& Lafrance, S. (2012). Structural violence in long-term, residential care for older people: comparing Canada and Scandinavia. Social Science and Medicine, 74(3), 390-398. doi: 10.1016/j.socscimed.2011.10.037

Barken, R., Daly, T.J., \& Armstrong, P. (2016). Family matters: the work and skills of family/friend carers in long-term residential care. Journal of Canadian Studies, 50(2), 321-347. doi: 10.3138/jcs.50.2.321

Brassolotto, J., Daly, T., Armstrong, P., \& Naidoo, V. (2017). Experiences of moral distress by privately hired companions in Ontario's long-term care facilities. Quality in Ageing and Older Adults, 18(1), 58-58. doi: 10.1109/QAOA-12-2015-0054.

Brown, K., \& Korczynski, M. (2017). The caring self within a context of increasing rationalization: the enduring importance of clients for home care aides. Sociology, 51(4), 833-849. doi: $10.1177 / 0038038515608112$ 
This document is the author's version of an accepted manuscript of a published work that appeared in final form in Ageing and Society, copyright (C) Cambridge University Press, after peer review and technical editing by the publisher. To access the final edited and published work see [https://doi.org/10.1017/S0144686X19000138].

Bruce, E. (2004). Social Exclusion (and Inclusion) in Care Homes. In Dementia and Social Inclusion (pp. 123-135). London, Philadelphia: Jessica Kingsley.

Canadian Institute for Health Information (2013). When a nursing home is home: How do Canadian nursing homes measure up on quality? Ottawa, ON: CIHI.

Centre on Aging (2014). Health status and health care use (Quickfacts) Winnipeg, MB: University of Manitoba. Accessed at: http://umanitoba.ca/centres/aging/media/CoA_Profile_Quickfacts_2014_health_status_FI NAL_web.pdf

Cooke, H., Puurveen, G., \& Baumbusch, J. (2017) "It's the nature of the person": Critically exploring family members' perceptions of residential care aides in long-term care. Paper presented at the 46th Annual Scientific and Educational Meeting of the Canadian Association on Gerontology, Winnipeg, MB (Oct 21).

Cossever, F. (2006). Private companions in long term care. Long Term Care. 16(3): 18-20.

Coughlan, R. \& Ward, L. (2007). Experiences of recently relocated residents of a long-term care facility on Ontario: Assessing quality qualitatively. International Journal of Nursing Studies, 44, 47-57. doi: 10.1016/j.ijnurstu.2005.11.022

Daly, T., Struthers, J., Muller, B., Taylor, D., Goldmann, M., Doupe, M., et al. (2016). Prescriptive or interpretive regulation at the frontlines of care work in the "three worlds" of Canada, Germany and Norway. Labour/Le Travail, 77, 37-71. doi:

10.1353/llt.2016.0029 
This document is the author's version of an accepted manuscript of a published work that appeared in final form in Ageing and Society, copyright (C) Cambridge University Press, after peer review and technical editing by the publisher. To access the final edited and published work see [https://doi.org/10.1017/S0144686X19000138].

Daly, T., \& Armstrong, P. (2016) Liminal and invisible long-term care: precarity in the face of austerity. Journal of Industrial Relations, 58(4), 473-490. doi:

\section{$10.1177 / 0022185616643496$.}

Daly, T., Armstrong, P, \& Lowndes, R. (2015). Liminality in Ontario's long-term care facilities: Private companions' care work in the space 'betwixt and between.' Competition and Change, 19(3), 246-263. doi: 10.1177/1024529415580262

Daly, T., Banerjee, A., Armstrong, P., Armstrong, H., \& Szebehely, M. (2011). Lifting the 'violence veil': Examining working conditions in long-term care facilities using iterative mixed methods. Canadian Journal on Aging, 30(2), 271-284. doi:

\subsection{7/S071498081100016X}

Daly, T. \& Szebehely, M. (2011). Unheard voices, unmapped terrain: Care work in long-term residential care of older people in Canada and Sweden. International Journal of Social Welfare, 21(2), 139-148. doi: 10.1111/j.1468-2397.2011.00806.x

Degiuli, F. (2010). The burden of long-term care: how Italian family care-givers become employers. Ageing and Society, 30(5), 755-777. doi: 10.1017/S0144686X10000073

Degiuli, F. (2016). Caring for a Living: Migrant women, aging citizens, and Italian families. New York: Oxford University Press.

Dobbs, D., Eckert, J. K., Rubinstein, B., Keimig, L., Clark, L., Frankowski, A. C., \& Zimmerman, S. (2008). An ethnographic study of stigma and ageism in residential care or assisted living. Gerontologist, 48(4), 517-526. doi: 10.1093/geront/48.4.517

Dodson, L., \& Zincavage, R.M. (2007). “'It's like a family”: caring labor, exploitation, and race in nursing homes. Gender and Society, 21(6), 905-928. doi: 10.1177/0891243207309899 
This document is the author's version of an accepted manuscript of a published work that appeared in final form in Ageing and Society, copyright (C) Cambridge University Press, after peer review and technical editing by the publisher. To access the final edited and published work see [https://doi.org/10.1017/S0144686X19000138].

Doupe, M., Brownell, M., Kozyrskyj, A., Dik, N., Burchill, C., Dahl, M., et al. (2006). Using Administrative Data to Develop Indicators of Quality Care in Personal Care Homes. Winnipeg, MB: Manitoba Centre for Health Policy. Accessed at: http://mchpappserv.cpe.umanitoba.ca/reference/pch.qi.pdf

Dergal, J. (2011). Family Members' Use of Private Companions in Nursing Homes: A mixed methods study. Doctoral Dissertation, University of Toronto. Accessed at: http://hdl.handle.net/1807/31734

Duffy, M., Armenia, A., \& Stacey, C.L. (2015). On the clock, off the radar: Paid care work in the United States. In M. Duffy, A. Armenia \& C.L. Stacey (Eds.), Caring on the Clock: The complexities and contradictions of paid care work (pp.3-13). New Brunswick, NJ:

Rutgers.

Folbre, N., \& Nelson, J.A. (2000). For love or money - or both? Journal of Economic Perspectives, 14(4), 123-140. doi: 10.1257/jep.14.4.123

Funk, L.M., \& Roger, K.S. (2017). Implications of the shifting landscape of residential care for volunteers' lived experiences and role involvement. Ageing International, 42(1): 44-61. doi: $10.1007 / \mathrm{s} 12126-016-9277-\mathrm{z}$

Gilleard, C., \& Higgs, P. 2010. Aging without agency: Theorizing the fourth age. Aging and Mental Health, 14(2): 121-8. doi: 10.1080/13607860903228762

Gubrium, J. F. \& J.A. Holstein. 2000. Analyzing interpretive practice. In N.K. Denzin \& Y.S. Lincoln (Eds.), The SAGE Handbook of Qualitative Research (pp. 487-508). Thousand Oaks, CA: Sage. 
This document is the author's version of an accepted manuscript of a published work that appeared in final form in Ageing and Society, copyright (C) Cambridge University Press, after peer review and technical editing by the publisher. To access the final edited and published work see [https://doi.org/10.1017/S0144686X19000138].

Harper Ice, G. (2002). Daily life in a nursing home: has it changed in 25 years? Journal of Aging Studies, 16(4), 345-359. doi: 10.1016/S0890-4065(02)00069-5

Hasson, H., \& Arnetz. J.E. (2011). Care recipients' and family members' perceptions of quality of older people care: a comparison of home-based care and nursing homes. Journal of Clinical Nursing, 20(9-10), 1423-1435.

Johnson, E.K. (2015). The business of care: the moral labour of care workers. Sociology of Health and Illness, 37(1), 112-126.

Keefe, J., Légaré, J., Charbonneau, P., \& Décarie, Y. (2012). Intergenerational support to older Canadians by their adult children: Implications for the future. In G. De Santis (Ed.), The Family, the Market or the State? International Studies in Population Vol. 10 (pp. 141158). Springer: Netherlands.

Lloyd, L., Banerjee, A., Harrington, C., Jacobsen, F.F., and Szebehely, M. (2014). It is a scandal!: Comparing the causes and consequences of nursing home media scandals in five countries. International Journal of Sociology and Social Policy, 34(1/2), 2-18. doi: 10.1108/IJSSP-03-2013-0034.

McGregor, M.J., Tate, R.B., Ronald, L.A., McGrail, K.M., Cox, M.B., Berta, W., \& Broemeling, A.M. (2010). Trends in long-term care staffing by facility ownership in British Columbia, 1996 to 2006. Health Reports, Statistics Canada. 21(4), 27-33.

McParland, P., Kelly, F., \& Innes, A. 2017. Dichotomising dementia: is there another way? Sociology of Health and Illness, 39(2): 258-69. doi: 10.1111/1467-9566.12438 Manitoba Nurses Union (2018). The Future of Long-Term Care is Now: Addressing nursing care needs in Manitoba's personal care homes. Winnipeg, MB: MNU. 
This document is the author's version of an accepted manuscript of a published work that appeared in final form in Ageing and Society, copyright (C) Cambridge University Press, after peer review and technical editing by the publisher. To access the final edited and published work see [https://doi.org/10.1017/S0144686X19000138].

Mead, G.H. (1934). Mind, Self and Society. University of Chicago Press: Chicago, IL.

Miller, E.A., Tyler, D.A., Rozanova, J., and Mor, V. (2012). National newspaper portrayal of U.S. nursing homes: periodic treatment of topic and tone. Milbank Quarterly, 90(4), 725761. doi: /10.1111/j.1468-0009.2012.00681.x

Novek, S. (2013). Filipino health care aides and the nursing home labour market in Winnipeg. Canadian Journal on Aging, 32(4), 405-416. doi: 10.1017/S071498081300038X

Outcalt, L. (2013). Paid companions: a private care option for older adults. Canadian Journal on Aging, 32(1), 87-102. doi: 10.1017/S0714980813000093

Shenk, D. (2009). Moral agency of direct care workers and the people for whom they care. Journal of Aging, Humanities and the Arts, 2(4), 285-299. doi:10.1080/19325610903295495

Stacey, C.L. (2011). The Caring Self: The work experiences of home care aides. Ithaca, NY: ILR Press.

Stacey, C.L. (2005). Finding dignity in dirty work: the constraints and rewards of low-wage home care labour. Sociology of Health and Illness, 27(6), 831-854. doi: 10.1111/j.14679566.2005.00476.x

Vourlekis, B.S., Gelfand, D.E., \& Greene, R.R. (1992). Psychosocial needs and care in nursing homes: comparison of views of social workers and home administrators. Gerontologist, 32(1), 113-119. doi: 10.1093/geront/32.1.113

1 These vary by province. For instance, see Manitoba's Personal Care Homes Standards Regulation: https://web2.gov.mb.ca/laws/regs/current/_pdf-regs.php?reg=30/2005 
This document is the author's version of an accepted manuscript of a published work that appeared in final form in Ageing and Society, copyright (C) Cambridge University Press, after peer review and technical editing by the publisher. To access the final edited and published work see [https://doi.org/10.1017/S0144686X19000138].

2 In Canada, acceptable recreation worker training varies by province and by facility; the profession is unregulated. Many nursing homes prefer at least a college certificate in Therapeutic Recreation; this is the only program available in the province (in contrast to the U.S. which offers nationally certified specialist programs).

3 This standardized item in the RAI-MDS is based on six 'yes-no' items such as "at ease interacting with others" (Armstrong, Daly and Choiniere, 2016: 355) 